\title{
Prevalence of Ectoparasite Infestation in Chicken in and Around Ambo Town, Ethiopia
}

\author{
Firaol Tamiru*, Dagmawit A, Askale G, Solomon S, Morka D and Waktole T
}

Department of Veterinary Laboratory Technology, College of Agriculture and Veterinary Sciences, Ambo University, Ethiopia

\begin{abstract}
A cross sectional study was conducted from July to October 2013 to estimate prevalence and identify different species of ectoparasites infesting chicken in semi-intensive and backyard chicken farms in and around Ambo Town, West Shewa, Ethiopia. A total of 390 chickens were randomly selected. Age, sex, breed and management system of the study population was simultaneously recorded. Ectoparasites were collected from different parts of the body including shank scraping and identified with stereomicroscopy or light microscopy. An overall 67.95\% (265/390) prevalence was recorded and five species of ectoparasites under three orders (Phthiraptera (lice), Siphonaptera (flea) and mite were identified. The prevalence of pediculosis, flea infestation and mange were $52.1 \%, 44.36 \%$ and $34.62 \%$, respectively. Three species of lice (Cuclotogaster heterographa (50\%), Menacanthus stramineus (1.28\%) and Lipeurus caponis (6.15\%)), one species of flea (Echidnophaga gallinacean (44.36\%)) and mite (Cnemidocoptes mutans $(34.62 \%)$ ) were identified. Higher prevalence rate was recorded in male $(83.89 \%)$ than female $(58.09 \%)$, young $(74.45 \%)$ than adult $(61.79 \%)$ and local $(87.55 \%)$ than exotic $(26.4 \%)$ breed chicken. There was no infestation of chicken with ectoparasite in semi-intensive farming system while $87.46 \%(265 / 303)$ of chickens kept under extensive management system were infested. Statistically, there was significance difference between categories of sex $\left(x^{2}=28.145, p<0.05\right)$, age $\left(x^{2}=8.083, p<0.05\right)$, management $\left(x^{2}=2.37, p<0.05\right)$ and breed $\left(x^{2}=1.458, p<0.05\right)$ groups in prevalence of ectoparasite infestation $(p<0.05)$. Male, young and local breed chicken groups were 3.757 $(\mathrm{Cl}=2.265-6.234), 1.883(\mathrm{Cl}=1.214-2.921)$ and $19.6(11.427-33.618)$ times more likely infested by ectoparasite than female, adult and cross breed groups, respectively. In conclusion, infestation of chicken with ectoparasites was important constraint in poultry production sector. Therefore, application of integrated control strategy, good management practices, creation of awareness and further detailed study were recommended.
\end{abstract}

Keywords: Ambo; Ectoparasites; Infestation; Risk factors; Chickens; Prevalence

\section{Introduction}

Ethiopia accounts 42 million poultry population [1] from the total 18 billion of the world's population [2]. About $80 \%$ of poultry population in Africa and Asia are kept under free range system [3]. From the total population of chicken in Ethiopia, 99\% are raised under the traditional back yard management system [4] with inadequate housing, feeding and health care $[2,5]$.

In developing countries, animal production is being subjected to great pressure to satisfy the demand for animal protein required by the continued increase in human population, and also to have surplus for international trade. Among the animal production activities, poultry sector is the fastest growing. Nevertheless, it has been adversely affected by a variety of constraints [6]. Among the constraints, parasitism ranks top in village chicken production [7].

External parasites of poultry are common in the tropics because of the favourable climatic conditions for their development and the poor standards of poultry husbandry. Some of the ectoparasites are of particular importance as vectors of pathogens and host specific [8]. They can inhibit the skin or outgrowths of the skin of the host organism for various periods [9]. Some are blood suckers while others burrow in the skin or live on or in the feathers [10]. Ectoparasites, such as ticks, mites and fleas, live on domestic chickens. Mites have long been recognized as a cause of dermatitis and skin damage on all classes of poultry [11].

Despite their devastating effects, ectoparasites received little attention in almost all the production systems. Hence, study with regard to determining magnitudes of such parasites and identifying their types is fundamental to devise appropriate control methods [12]. However, no studies were conducted on poultry ectoparasites in and around Ambo town, Ethiopia, where chicken are source of income generation and food. Thus, the current study was undertaken to determine the prevalence of chickens' ectoparasite, identifies species of ectoparasites infesting chicken and assess potential risk factors.

\section{Methods}

\section{Study area}

The study was conducted from July to October, 2013 in and around Ambo town, West Shewa zone, Ethiopia. Ambo town is administrative center of West Shewa zone and Ambo district, and located at a latitude and longitude of $8^{\circ} 59^{\prime} \mathrm{N} 37^{\circ} 51^{\prime} \mathrm{E} 8.983^{\circ} \mathrm{N} 37.85^{\circ} \mathrm{E}$ and an elevation of 2101 meters above sea level (asl) and $114 \mathrm{Km}$ west of Addis Ababa, capital of Oromia region and Ethiopia. The agro-ecology of the study area is $23 \%$ highland, $60 \%$ midland, and $17 \%$ lowland. It has an annual rainfall and temperature ranging from $800-1000 \mathrm{~mm}$ and $20-29^{\circ} \mathrm{C}$, respectively. The livestock population of the district includes 145371 cattle, 50152 sheep, 27026 goats, 105794 chickens, 9088 horses, 2914 donkeys and 256 mules [13].

*Corresponding author: Firaol Tamiruebede, Department of Veterinary Laboratory Technology, College of Agriculture and Veterinary Sciences, Ambo University, Ethiopia; Tel: +251910856904, E-mail: tfiraol@gmail.com

Received August 02, 2014; Accepted August 28, 2014; Published August 30, 2014

Citation: Firaol Tamiru, Dagmawit A, Askale G, Solomon S, Morka D, et al. (2014) Prevalence of Ectoparasite Infestation in Chicken in and Around Ambo Town, Ethiopia. J Veterinar Sci Technol 5: 189. doi:10.4172/2157-7579.1000189

Copyright: (c) 2014 Firaol Tamiru, et al. This is an open-access article distributed under the terms of the Creative Commons Attribution License, which permits unrestricted use, distribution, and reproduction in any medium, provided the original author and source are credited. 
Citation: Firaol Tamiru, Dagmawit A, Askale G, Solomon S, Morka D, et al. (2014) Prevalence of Ectoparasite Infestation in Chicken in and Around Ambo Town, Ethiopia. J Veterinar Sci Technol 5: 189. doi:10.4172/2157-7579.1000189

Page 2 of 5

Even though there is some initiation for semi-intensive and intensive farming system, traditional farming system is still the dominant. Both local and exotic breeds chicken are raised in the area with predomination of local breed.

\section{Study design and animals}

A cross sectional study was conducted on a total of 390 local and exotic (Rhodes Island Red (RIR)) breeds from both sexes of chickens. The chickens were randomly selected from backyard chickens and selected semi-intensive farms. Information on the breed and management system was obtained from the owners and by assessment. Age of the chickens was determined by observing color of the shank and growth of the spur and categorized as young (less than 12 weeks of age) and adult (greater than 12 weeks of age).

\section{Study protocols}

All parts of the chickens were thoroughly inspected using naked eyes and hand lens. Ectoparasites were collected by hand picking and nontoothed thumb forceps. The collected parasites were further examined by light or stereomicroscope and identified according to guidelines of William [14]. Shank scraps were collected on clean petri-dish. Wet film was prepared from the scrap and $10 \%$ potassium hydroxide was used to emulsify debris and examined under light or stereomicroscope.

\section{Data analysis}

The collected data were coded and entered in to Microsoft Excel spread sheet and analyzed using Statistical software for Social Sciences (SPSS) version 16.0. Frequency was used to calculate the prevalence. Chi-square was used to test the statistical significance difference between the risk factor groups in prevalence of ectoparasite infestation. Odd ratio was used to estimate risk in groups of risk factors at $95 \%$ confidence interval $(\mathrm{CI})$. P-value less than $0.05(\mathrm{p}<0.05)$ was considered as statistical significance difference.

\section{Results}

An overall 67.95\% (265/390) prevalence of ectoparasites infestation

Table 1: Prevalence and species of ectoparasites identified in and around Ambo town.

\begin{tabular}{|c|c|c|c|}
\hline \multicolumn{2}{|c|}{ Parasite } & \multirow{2}{*}{$\begin{array}{l}\text { No. of chickens } \\
\text { examined }\end{array}$} & \multirow{2}{*}{$\begin{array}{l}\text { No. of positive (\%) } \\
\text { chickens }\end{array}$} \\
\hline Order & Species & & \\
\hline Sinophtera (flea) & E. gallinacean & 390 & $173(44.36)$ \\
\hline Mite & C. mutans & 390 & $135(34.62)$ \\
\hline \multirow{3}{*}{ Phthinaptera (lice) } & L. caponis & 390 & $24(6.15)$ \\
\hline & M. stramineus & 390 & $5(1.28)$ \\
\hline & C. heterographa & 390 & $195(50)$ \\
\hline \multicolumn{2}{|l|}{ Total } & 390 & 265 (67.95) \\
\hline
\end{tabular}

was recorded. Positive chickens were found to harbor one or more parasites. About $70.94 \%$ (188/265) of positive chickens or $48.21 \%$ of the total examined chickens (188/390) were found to be infested with more than one species of ectoparasites while $29.06 \%$ (77/265) of the positive chickens or $19.74 \%$ (77/390) of total examined chickens were infested with single species. Five species of ectoparasites categorized under three orders, Echidnophaga gallinacean (E. gallinacean) (order: Sinophtera or flea), Cnemidocoptes mutans (C. mutans) (order: mite) and three species of Phthinaptera or lice order including Cuclotogaster heterographa (C. heterographa) (head lice), Lipeurus caponis (L. caponis) (wing lice) and Menacanthus stramineus (M. stramineus) (body lice) were identified. Cuclotogaster heterographa (50\%) was the most prevalent species followed by E. gallinacean (44.36\%) and C. mutans (34.62\%) while M. stramineus $(1.28 \%$ ) was least prevalent one followed by L. caponis $(6.15 \%)$ (Table 1$)$.

Prevalence of the infestation was higher in male $(83.89 \%)$ than female $(58.09 \%)$, young $(74.45 \%)$ than adult $(61.79 \%)$ and local (87.55\%) than exotic (26.4\%) breed chickens. There was no infestation of chickens with ectoparasite in semi-intensive farming system while $87.46 \%(265 / 303)$ of chickens kept under extensive management system were infested. Statistically, there was significance difference between categories of sex $\left(\chi^{2}=28.145, p<0.05\right)$, age $\left(\chi^{2}=8.083, p<0.05\right)$, management $\left(\chi^{2}=2.37, \mathrm{p}<0.05\right)$ and breed $\left(\chi^{2}=1.458, \mathrm{p}<0.05\right)$ groups in prevalence of ectoparasite infestation $(\mathrm{p}<0.05)$. Male, young and local breed chicken categories were $3.757(\mathrm{CI}=2.265-6.234), 1.883$ $(\mathrm{CI}=1.214-2.921)$ and $19.6(11.427-33.618)$ times more likely infested by ectoparasite than female, adult and cross breed categories, respectively (Table 2).

Overall 52.1\% (203/390) prevalence of pediculosis was recorded. It was higher in male (65.77\%), young $(60.67 \%)$ and local breed (66.42\%) groups than female (43.57\%), adult (44.81\%) and exotic breed (21.6) groups, respectively. There was no infestation in semi-intensive management system while $67 \%$ (176/390) was recorded in extensive farming system. There was statistical significance difference between categories of sex $\left(\chi^{2}=18.187, \mathrm{p}<0.05\right)$, age $\left(\chi^{2}=9.755, \mathrm{p}<0.05\right)$, breed $\left(\chi^{2}=68.349, \mathrm{p}<0.05\right)$ and management (Fisher's exact $\left.=1.216, \mathrm{p}<0.05\right)$ groups. Male (2.489 times), young (1.9 times) and local breed (7.178 times) chickens had more chance to encounter infestation than female, adult and exotic breed chickens, respectively (Table 3 ).

Pediculosis (52.1\%) was the most prevalent (Table 3) followed by flea infestation (44.36\%) while cnemidocoptic mange (34.62\%) was the least prevalent. Prevalence of E. gallinacean and C. mutans was higher in male, young and local breed chicken while L. caponis prevalence was higher in male, adult and local breed. Menacanthus stramineus was more prevalent in female, adult and local breed whereas $C$. heterographa was prevalent in female, young and local breed. Chickens kept under

Table 2: Prevalence of chicken ectoparasite and its association with hypothesized risk factors.

\begin{tabular}{|c|c|c|c|c|c|c|c|}
\hline Factor & Categories & No. examined & Positive (prevalence- \%) & OR & $95 \% \mathrm{Cl}$ & $\mathrm{X}^{2} /$ Fisher's exact & $\mathrm{p}$-value \\
\hline \multirow{2}{*}{ Sex } & Female & 241 & $140(58.09)$ & 1 & \multirow{2}{*}{$2.265-6.234$} & \multirow{2}{*}{28.145} & \multirow{2}{*}{0.000} \\
\hline & Male & 149 & 125 (83.89) & 3.757 & & & \\
\hline \multirow{2}{*}{ Age } & Young & 178 & $134(74.45)$ & 1.883 & \multirow{2}{*}{$1.214-2.921$} & \multirow{2}{*}{8.083} & \multirow{2}{*}{0.004} \\
\hline & Adult & 212 & $131(61.79)$ & 1 & & & \\
\hline \multirow{2}{*}{ Breed } & Local & 265 & $232(87.55)$ & 19.600 & \multirow{2}{*}{$11.427-33.618$} & \multirow{2}{*}{1.458} & \multirow{2}{*}{0.000} \\
\hline & Exotic & 125 & $33(26.4)$ & 1 & & & \\
\hline \multirow{3}{*}{ Management } & Extensive & 303 & $265(87.46)$ & - & \multirow{2}{*}{ - } & \multirow{2}{*}{2.37} & \multirow{2}{*}{0.000} \\
\hline & Semi-intensive & 87 & 0 & - & & & \\
\hline & Total & 390 & $265(67.95)$ & & & & \\
\hline
\end{tabular}


Citation: Firaol Tamiru, Dagmawit A, Askale G, Solomon S, Morka D, et al. (2014) Prevalence of Ectoparasite Infestation in Chicken in and Around Ambo Town, Ethiopia. J Veterinar Sci Technol 5: 189. doi:10.4172/2157-7579.1000189

Page 3 of 5

Table 3: Prevalence of chicken pediculosis and its association with risk factors.

\begin{tabular}{|c|c|c|c|c|c|c|c|}
\hline Factors & Category & No. examined & $\begin{array}{l}\text { No. of positive } \\
\text { (Prevalence in \%) }\end{array}$ & OR & $\mathrm{Cl}(95 \%)$ & $\mathrm{X}^{2} /$ Fishers'exact & $\begin{array}{l}\mathrm{P} \text { - } \\
\text { value }\end{array}$ \\
\hline \multirow{2}{*}{ Sex } & Female & 241 & $105(43.57)$ & 1 & \multirow{2}{*}{$3.801-1.630$} & \multirow{2}{*}{18.187} & \multirow{2}{*}{0.000} \\
\hline & Male & 149 & $98(65.77)$ & 2.489 & & & \\
\hline \multirow{2}{*}{ Age } & Young & 178 & $108(60.67)$ & 1.900 & \multirow{2}{*}{$1.268-2.848$} & \multirow{2}{*}{9.755} & \multirow{2}{*}{0.002} \\
\hline & Adult & 212 & $95(44.81)$ & 1 & & & \\
\hline \multirow{2}{*}{ Breed } & Local & 265 & $176(66.42)$ & 7.178 & \multirow[b]{2}{*}{$4.369-11.792$} & \multirow[b]{2}{*}{68.349} & \multirow[b]{2}{*}{0.000} \\
\hline & Exotic & 125 & $27(21.6)$ & 1 & & & \\
\hline \multirow[b]{2}{*}{ Management } & Extensive & 303 & $203(67.00)$ & - & & \multirow{2}{*}{1.216} & \multirow{2}{*}{0.000} \\
\hline & Semi-intensive & 87 & 0 & - & & & \\
\hline \multicolumn{2}{|l|}{ Total } & 390 & $203(52.1)$ & & & & \\
\hline
\end{tabular}

Table 4: Prevalence, risk estimate, presence or absence of statistical significance difference in prevalence for each species of identified ectoparasites.

\begin{tabular}{|c|c|c|c|c|c|c|c|}
\hline \multirow{2}{*}{ Factors } & \multirow{2}{*}{ Category } & \multirow{2}{*}{ No. examined } & \multicolumn{5}{|c|}{ No. of positive (prevalence in \%) } \\
\hline & & & E. gallinacean & C. mutans & L. caponis & M. stramineus & C. heterographa \\
\hline \multirow{6}{*}{ Sex } & Female & 241 & $85(35.27)$ & $63(26.14)$ & $11(4.56)$ & $4(1.67)$ & $99(41.08)$ \\
\hline & Male & 149 & $88(59.06)$ & $72(48.32)$ & $13(8.72)$ & $1(0.67)$ & $96(64.43)$ \\
\hline & $\mathrm{X}^{2} /$ Fishers'exact & & 21.114 & 20.015 & 2.760 & 0.711 & 20.082 \\
\hline & $p$-value & & 0.000 & 0.000 & 0.097 & 0.653 & 0.000 \\
\hline & $\mathrm{OR}(\mathrm{M} / \mathrm{F})$ & & 2.648 & 2.642 & - & - & 2.598 \\
\hline & $95 \% \mathrm{Cl}$ & & $1.740-4.030$ & $4.066-1.717$ & - & - & $1.703-3.963$ \\
\hline \multirow{6}{*}{ Age } & Young & 178 & $86(48.31)$ & $76(42.67)$ & $11(6.18)$ & $2(1.12)$ & $105(58.98)$ \\
\hline & Adult & 212 & $87(41.03)$ & $59(27.83)$ & $13(6.13)$ & $3(1.42)$ & $90(42.45)$ \\
\hline & $\mathrm{X}^{2} /$ Fishers'exact & & 2.076 & 9.448 & 0.000 & 0.065 & 10.583 \\
\hline & $p$-value & & 0.150 & 0.002 & 0.984 & 1.000 & 0.001 \\
\hline & $\mathrm{OR}(\mathrm{Y} / \mathrm{A})$ & & - & 1.932 & - & - & 1.950 \\
\hline & $95 \% \mathrm{Cl}$ & & - & $1.267-2.948$ & - & - & $1.301-2.921$ \\
\hline \multirow{6}{*}{ Breed } & Local & 265 & $145(54.71)$ & $130(49.06)$ & $19(7.160$ & $4(1.51)$ & $170(64.15)$ \\
\hline & Exotic & 125 & $28(22.4)$ & $5(4)$ & $5(4)$ & $1(0.8)$ & $25(20)$ \\
\hline & $X^{2} /$ Fishers'exact & & 35.940 & 76.184 & 1.478 & 0.338 & 66.226 \\
\hline & p-value & & 0.000 & 0.000 & 0.224 & 1.000 & 0.000 \\
\hline & OR (L/E) & & 4.186 & 23.111 & - & - & 7.158 \\
\hline & $95 \% \mathrm{Cl}$ & & 2.577-6.799 & $9.151-58.368$ & - & - & $4.319-11.861$ \\
\hline \multirow{4}{*}{ Management } & Extensive & 303 & $173(57.1)$ & $135(44.55)$ & $24(7.92)$ & $5(1.65)$ & $195(64.35)$ \\
\hline & Semi-intensive & 87 & 0 & 0 & 0 & 0 & 0 \\
\hline & $\mathrm{X}^{2} /$ Fishers'exact & & 89.275 & 59.284 & 7.343 & 1.454 & 1.120 \\
\hline & $p$-value & & 0.000 & 0.000 & 0.004 & 0.591 & 0.000 \\
\hline
\end{tabular}

Keys: M- male, F-female, Y-young, A-adult, L-local, E-exotic

extensive management system were frequently infested while no chicken kept under semi-intensive management system was infested by ectoparasite. Prevalence, presence or absence of statistical significance difference in prevalence of each species of identified ectoparasites and the risk estimate for variables are given in Table 4.

\section{Discussion}

Ectoprasites are important constraints to poultry production sector. Some parasites exist only on one defined area of the host's body while others can exploit wider range of hosts [15]. The observed overall prevalence of $67.95 \%$ of ectoaparasite infestation in the current study is comparable to $70.73 \%$ report from Meerut [16]. However, higher prevalence rate of $91.5 \%$ [5], 86.67\% [17] and 100\% [3] were recorded in East Shoa zone (Ethiopia), Bangladesh and Nigeria, respectively. The difference between the current and previous findings may be due to breed, seasonal, management, agroecological, and implemented methods of the disease control and prevention $[18,19]$. The current study was undertaken during heavy rainy season (July to October) while others like Belihu et al. [5] was conducted in dry and short rainy season.

Positive chickens were found to harbor one or more ectoparasite species. About $48.21 \%$ of the total examined chickens were found to be infested with more than one species while $19.74 \%$ were infested with single species. Slight higher mixed infestation (67.4\%) was reported from Haramaya intensive poultry farm, Ethiopia [12]. From the positive chickens, about $70.94 \%$ and $29.04 \%$ chickens were infested with mixed and single infestation, respectively. However, $19 \%$ single and $81 \%$ mixed infestation were recorded in Iraq [20]. The observed variation in the proportion of single and mixed infestation would be related to difference of implemented management system. 
Citation: Firaol Tamiru, Dagmawit A, Askale G, Solomon S, Morka D, et al. (2014) Prevalence of Ectoparasite Infestation in Chicken in and Around Ambo Town, Ethiopia. J Veterinar Sci Technol 5: 189. doi:10.4172/2157-7579.1000189

Page 4 of 5

Pediculosis (52.1\%) was the most prevalent followed by flea infestation $(44.36 \%)$ while mange $(34.62 \%)$ was the least prevalent. The current study is consistent with report from Wolayta Soddo town, Southern Ethiopia, in which $88 \%$ lice, $16.5 \%$ flea and $8.1 \%$ mite was reported [19]. Similarly, highest prevalence of lice infestation (90\%) was reported from Kenya [21]. This may be related to favourable climatic condition in tropics for their development [8].

Five species of ectoparasites, namely E. gallinacean, C. mutans, and C. heterograha, M. stramineus and L. caponis, were identified in the present study. Most of these species were reported from different parts of Ethiopia [5,12,19], Nigeria [3] and Bangeladesh [17]. This indicates widespread of these ectoparasite species.

Among the identified ectoparasite species, C. heterograha was most frequently identified (50\%) species while M. stramineus (1.28\%) was the least one. However, highest prevalence of $70 \%$ and $65.33 \%$ M. stramineus was reported from Bangladesh [17] and Ethiopia [5], respectively. In Iran, $40 \%$ of chickens harbored M. stramineus, but the prevalence of $C$. heterograha was $8 \%$ [22]. The prevalence of $6.15 \%$ of $L$. caponis is comparable to $5 \%$ reported by Bala et al. [3], but higher than $0.67 \%$ report of Belihu et al. [5], and much lower than 32\% [22] and $48 \%$ [17]. Prevalence of E. gallinacean (44.4\%) is in line of agreement with 51.16\% in East Shoa, Ethiopia [5]. Cnemidocoptes mutans (34.5\%) in the present study is higher than reports of $9.4 \%$ [3] and $0.89 \%$ [23]. The difference might be due to management, climatic and geographic (altitudinal) difference among these studies.

Higher infestation rate observed in male than female chickens with presence of statistical significance difference in current study is consistent with finding of Belihu et al. [5]. According to Mekuria and Gezahegn [19] and Bala et al. [3], the infestation was higher in female than male group. Young chickens were more affected $(74.5 \%)$ than adult chickens (61.79\%) with 1.9 times greater probability to acquire the infestation. This result disagrees with the finding of Sabuni et al. [21] and Nnadi and George [7] where $100 \%$ and $92 \%$ of adult and young chickens were infested, respectively with statistical significance difference. Management difference in different study areas may attribute to such differences.

Local breed chickens (87.55\%) were more infested than exotic breed chickens $(26.4 \%)$ with statistical significance difference. Slightly comparable finding of $2.35 \%$ was reported from Debrezeit semiintensive farm [24] and $100 \%$ in free ranging chickens [3]. Local breeds are allowed to free-range, thus becoming more vulnerable to ectoparasitism than exotic breed, which are almost kept in indoor. In this study, the prevalence was nil in semi-intensive management system while it was $87.46 \%$ in extensive management system, which is similar with work of Mekuria and Gezahegn [19]. This is due to better measures and practices related to good housing, feeding and husbandry system applied in semi-intensive farms where exotic breeds are kept.

In the current study, young chickens group were found 1.9 and 1.932 times more likely to be infested with lice species and C. mutans than adult chickens category, respectively. The result agrees with findings Mekuria and Gezahegn [19] where young chickens were 5.2 times more infested than adult chicken group and disagrees with 2.8 times more likely infestation of adult chickens than young chickens with C. mutans.

In conclusion, infestation of chickens with ectoparasites was important constraint of in the study area. Five species of ectoparasites were identified. Sex, age, breed and management were important risk factors with statistical significance difference. Therefore, application of integrated control strategy, good management practices, creation of awareness and further detailed study were recommended in the study area.

\section{Acknowledgement}

The authors are grateful to staffs of Department of Veterinary Laboratory Technology, Ambo University, Ethiopia and Ambo University for financial support.

\section{References}

1. CSA (2004) Agriculture Sample Enumeration Statistical Abstract, Central Statistical Authority, Federal Democratic Republic of Ethiopia.

2. Baboolal V, Suratsingh V, Gyan L, Brown G, Of?ah NV, ET AL. (2012) The prevalence of intestinal helminths in broiler chickens in Trinidad. Veterinarsk Arhiv 82: 591-597.

3. Bala AY, Anka SA, Waziri A, Shehu H (2011) Preliminary Survey of Ectoparasite Infesting Chickens (Gallus domesticus) in Four Areas of Sokoto Metropolis. Nigerian Journal of Basic and Applied Science 19: 173-180

4. Tadelle D, Million T, Alemu Y, Peters KJ (2003) Village Chicken Production System in Ethiopia: use patterns and performance evaluation and chicken products and socio-economic functions of chicken. DebreZeit Agricultural Research Centre, DebreZeit, Ethiopia. Livestock Research and Rural Development. 15

5. Belihu K, Mamo A, Lobago F, Ayana D (2010) Prevalence of Ectoparasites in Backyard Local Chickens in Three Agroecologic Zones of East Shoa in Ethiopia. Revue Méd. Vét: 160: 537-541.

6. FAO (1998) Village chicken production systems in rural Africa: Household food security and gender issues: FAO animal production and health paper 142 Rome.

7. Nnadi P, George S (2010) Prevalence of Parasites of the Village Chickens in Nigeria. J Parasitol Res.

8. Hopla CE, Durden LA, Keirans JE (1994) Ectoparasites and classification. Rev Sci Tech 13: 985-1017.

9. Durden LA, McLean RG, Oliver JH Jr, Ubico SR, James AM (1997) Ticks, Lyme disease spirochetes, trypanosomes, and antibody to encephalitis viruses in wild birds from coastal Georgia and South Carolina. J Parasitol 83: 1178-1182.

10. Bishop FC (1942) Poultry Lice and Their Control, USDA, Washington, DC USA.

11. Hobbenaghi R, Tavassoli M, Alimehr M, Shokrpoor S, Ghorbanzadeghan M (2012) Histopathological study of the mite biting (Dermanyssus gallinae) in poultry skin. Veterinary Research Forum 3: $205-208$.

12. Amede Y, Tilahun K, Bekele M (2011) Prevalence of Ectoparasites in Haramaya University Intensive Poultry Farm. Global Veterinaria 7: 264-269.

13. ATMA (2010) Ambo Town Ministry of Agricultural Office: Annual report. Ambo, Ethiopia.

14. William F (2001) Veterinary Parasitology Reference Manual. (5th ed), Blackwell, lowa.

15. Wall R, Shearer D (2001) Veterinary Ectoparasites: Biology, Pathology and Control. (2nd ed). Blackwell Science, Paris.

16. Kansal G, Singh HS (2014) Incidence of Ectoparasites in Broiler Chicken in Meerut. IOSR- JAVS 7: 55-58.

17. Shanta IS, Begum N, Anisuzzaman, Bari ASM, Karim MJ (2006) Prevalence and Clinico-Pathological Effects of Ectoparasites in Backyard Poultry. Bangl J Vet Med 4: 19-26.

18. Mungube EO, Bauni SM, Tenhagen BA, Wamae LW, Nzioka SM, et al. (2008) Prevalence of parasites of the local scavenging chickens in a selected semiarid zone of Eastern Kenya. Trop Anim Health Prod 40: 101-109.

19. Mekuria S, Gezahegn E (2010) Prevalence of External parasite of poultry in intensive and backyard chicken farm at Wolayta Soddo town, Southern Ethiopia. Vet. World 3: 533-538.

20. Al-Saffar TM, Al-Mawla ED (2008) Some hematological changes in chickens infected with ectoparasites in Mosul. Iraqi Journal of Veterinary Sciences 22 95-100.

21. Sabuni ZA, Mbuthia PG, Maingi N, Nyaga PN, Njagi LW, et al. (2010) Prevalence of ectoparasites infestation in indigenous free-ranging village chickens in different agro-ecological zones in Kenya. Livestock Research for Rural Development 22 (11).

22. Eslami A, Ghaemi P, Rahbari S (2009) Parasitic Infections of Free -Range Chickens from Golestan Province, Iran. J Parasitol 4: 10-14. 
Citation: Firaol Tamiru, Dagmawit A, Askale G, Solomon S, Morka D, et al. (2014) Prevalence of Ectoparasite Infestation in Chicken in and Around Ambo Town, Ethiopia. J Veterinar Sci Technol 5: 189. doi:10.4172/2157-7579.1000189

Page 5 of 5

23. Biu AA, Ahmed HA, Konto M, Paul BT (2012) survey of podoknemidokoptiasis in locally domesticated market chickens (Gallus gallus domesticus) in Maiduguri, Nigeria. Journal of Medical and Applied Biosciences 4: 39-46.
24. Tolossa $\mathrm{YH}$, Tafesse HA (2013) Occurrence of ectoparasites and gastrointestinal helminthes infections in Fayoumi chickens (Gallus gallus Fayoumi) in Debre Zeit Agricultural Research Center Poultry Farm, Oromia region, Ethiopia. Journal of Veterinary Medicine and Animal Health 5: 107-112. 